\title{
What Are We Going to Do about Them? The Centrality of Borders in Fortress Europe
}

\author{
SARA MARINO, King's College London
}

\begin{abstract}
Confronted with the images that have been reaching us since the influx of refugees entered new dimensions last year in Europe, the term 'Fortress Europe' has been used over and over again to identify the continent's concerns about security. What are we going to do with them? What do we know about them? All European governments seem to agree that a humanitarian state of urgency and emergency is on its way: a crisis of enormous proportions that is threatening the 'soul' and 'authentic spirit' of Europe. Across the Union, governments have struggled to develop an effective response, and mainly responded by transforming their borders into instruments of exclusion and prevention. This article discusses the centrality of the borders within the current political agenda, by conceptualising them as institutions of power, as processes of identity formation, and as performances. It focuses on the human costs of Fortress Europe, and its ongoing fight against the unwanted.
\end{abstract}

\section{KEYWORDS}

refugee crisis, bare life, state of exception, Agamben, Fortress Europe

\section{Introduction}

'What do we do with them? If these discourses generate a variety of metaphors positing "immigrants" as the source of a kind of societal illness, however, it ought to be clear that the rhetorical and critical force of this essay is directed at unsettling the ways that these discourses about 'immigration' are themselves expressions of a deadly cancer that courses continuously through the larger social formation of "the West"' (De Genova 2010, 407).

In 1985, the village of Schengen in Luxembourg was home to a crucial break-through in the history of Europe. The gradual abolition of checks at common borders, ratified in 1990, was considered the first step towards the political and economic unification of the continent. Twenty-seven years later, not only borders controls and internal security operations have become the norm rather than exceptional measures, as originally agreed in the Convention, but they have acted as an expression of global inequality and injustice against specific 'categories' of people. Especially in the last decade, Europe has become a 'borderland' (Balibar 2009) where "militarized instruments of exclusion and repression" (Carr 2015, 7) are commonly considered the most effective forms of prevention against external threats. Narratives of invasion and Europe's heightened concerns about security have fueled antiimmigrants discourses and crises of identity for years now, while opening up broader anxieties about the 'purity' of the nation states. As Bunyan notes, the EU has mutated into a security state, a massive fortification and a 'border enforcement regime' (2010; see also Carr 2015).

According to Amnesty International, more than $235 \mathrm{~km}$ of fences at the EU's external borders have been built, including: a $175 \mathrm{~km}$ fence along the Hungary-Serbia border, a 30 $\mathrm{km}$ fence along the Bulgaria-Turkey border, which is to be extended by a further $130 \mathrm{~km}$, 
$18.7 \mathrm{~km}$ of fences along the borders of the Spanish enclaves of Ceuta and Melilla with Morocco, and a $10.5 \mathrm{~km}$ fence in the Evros region along the Greece-Turkey border ${ }^{1}$.

These numbers are not, in any way, exhaustive; deciding who has the right to enter the legitimate territory of a nation, and who can merely survive outside these boundaries, is a never-ending work in progress. Rather, while the world is witnessing what has been defined as the worst refugee crisis since World War II, "Europe's borders are provisional and transitional boundaries in a political space that is still under construction" (Carr 2015, 25).

The article examines what Europe has become today, while considering the current refugee crisis (and the way it has been handled) as a crucial turning point in the development of fortresses and gates. In particular, it discusses the relationship between borders and violence, and between borders and bodies. The proliferation of bordering practices in contemporary political life will be examined in relation to the conceptualisation of the borders as institutions of power, as processes of identity formation, and as performances.

Drawing from Agamben's theory of bare life as 'life that may be killed without the commission of homicide' (1998, 91), and Vaughan-Williams's (2009) work on border politics as main reference points, this article argues that the proliferation of bordering and security practices has been accompanied by episodes of violence against the bodies of those in transit, which have been witnessed and reported by organisations such as Amnesty International and Human Rights Watch among many others.

The equation "border = body performances" is here deemed as necessary because what we are witnessing today is not merely a political or geopolitical issue: the human consequences of Fortress Europe are impossible to ignore, and undermine the principles of freedom and justice that the Schengen agreement proudly affirmed in 1985. There is a 'humanity on the move' that is now under the control of the EU's militarized borders, in reception and detention camps, while racism and xenophobia are boiling underneath, and quite often very explicitly. The Union is increasingly controlled and ruled by gates, cordons, biometric and policing measures, physical and bureaucratic barriers, naval patrols and satellite technologies that cost us billions of euros, while human beings die at sea, suffocate in trucks, freeze to death, or find themselves trapped in chokepoints like Calais, Hungary and Greece, unable to move forward or to go back.

As Matthew Carr rightly points out, 'the impact of border enforcements is always difficult to quantify'; however, 'despite the annual deportations and refusals of entry, the pushbacks and towbacks, the externalized border partnerships, the 'pre-entry' border control and punitive 'post-entry' policies toward asylum seekers [...], men, women and children have continued to find their way to Europe' (Carr 2015, 262). And yet, despite being the symbol of the Union's political and moral failures, borders have become a 'natural' form of protection that we accept without asking questions. Nevertheless, as John Dalhuisen, Europe and Central Asia Director at Amnesty International argues:

'Where there are fences, there are human rights abuses. Illegal push-backs of asylum-seekers have become an intrinsic feature of any EU external

1 Amnesty International's report Fear and Fences: Europe's approach to keeping refugees at bay (2015). Available from: https://www.amnesty.org/en/latest/news/2015/11/refugees-endangered-and-dying-due-to-eureliance-on-fences-and-gatekeepers/ 
border located on major migration routes and no one is doing much to stop them. [...] As long as there is violence and war, people will continue to come, and Europe must find better ways to offer protection. The EU and its front-line member states urgently need to rethink how they ensure safe and legal access to the EU both at its external land borders and in countries of origin and transit. This can be accomplished through the increased use of resettlement, family reunification and humanitarian visas ${ }^{2}$.

This article aims to shed light on the paradoxes and injustices that are, quite conveniently, not visible to the general public: from push-backs to mass deportations of asylum seekers, these people in desperate need are rarely consulted or given adequate protection. These people have no political or economic voice. These are lives that do not matter nor exist in the political discourse, as non-citizens, non-regular, non-legal indistinct forms of subjectivity. As a 'vague and underdetermined place created by the emotional residue of an unnatural boundary' (Anzaldùa, quoted in Carr 2015, 224), the borders reveal their inner complexity and multi faceted nature. It is, therefore, because of this complexity that the present article will distinguish between different features of the concept. In the following chapter, I discuss the borders as states of exception and as institutions of power, with a specific focus on Vaughan-Williams's seminal work on border politics and sovereign power (2009), and Agamben's States of Exception (2005). I then examine how the bordering practices can act as processes of identity formation, by taking into account Agamben's theory of bare life (1998) and Butler's Precarious Life (2004). Finally, I propose a conceptualization of the borders as performances of denial, or as political and communicative processes that rely on their normativity in order to be conveniently forgotten.

\section{Borders as states of exception and institutions of power}

'[...] there are many different types of borders that can be identified: divisions along ethnic, national or racial lines; class-based forms of stratification; regional and geographical differences; religious, cultural, and generational boundaries; and so on. None of these borders is in any sense given but (re)produced through modes of affirmation and contestation and is, above all, lived. In other words borders are not natural, neutral nor static but historically contingent, politically charged, dynamic phenomena that first and foremost involve people and their everyday lives' (Vaughan-Williams 2009, 1).

This section will focus on the artificiality of the borders as political and historical contingencies, and their impact on the lives of refugees. Far from being only a measure of international stability, dialogue and security, borders 'seek to confirm or inculcate a shared sense of identity and belonging and an exclusive set of national rights and privileges amongst the people who live inside them' (Carr 2015, 15).

2 Quote from Amnesty International's report Fear and Fences: Europe's approach to keeping refugees at bay (2015). Available from: https://www.amnesty.org/en/latest/news/2015/11/refugees-endangered-and-dying-dueto-eu-reliance-on-fences-and-gatekeepers/ 
The consequence of this 'us vs. them' dialectic will be under scrutiny here: while refugees die, border confrontations and diplomatic disputes over who is doing what are part of a seedy game-play of power and inequality, where only a few actors are allowed to participate. Fueled by 'narratives of invasion' and presented as the only solution possible to the 'organised incursion' of unwanted and unwelcomed people, the borders function as a "system of exclusion and control that is simultaneously ruthless, repressive, devious, chaotic and dysfunctional" (Carr 2015, 261). More importantly, we are also witnessing a shift from border enforcement to border sealing: what started in the early 2000s as a massive deployment of technological aids and personnel to combat terrorism and to maintain security, is now rapidly transforming into a global phenomenon of 'border sealing'. The back door to Europe is now an impossible route to take: Slovakia, Germany, Austria and Hungary among other countries, especially in the wake of the Paris attacks, have decided to seal their land borders as a consequence of perceived security threats. Germany and Austria have taken emergency measures after an initial 'open borders' policy, following the similar path of Finland and Sweden, which introduced tighter border controls and mass expulsions in order to reduce the number of immigrants that are allowed to enter the state.

Whether it is reinforced or sealed, the concept of the border is at the forefront of the current debate around immigration. However, we rarely come to terms with what this concept means, and what its implications are. This section focuses on the identification of the borders as states of exception where narratives of exclusion can 'legitimately' take place, and as zones of anomie. According to Agamben, a state of exception is a zone of indistinction where law and force overlap one another, a "no-man's-land between public law and political fact, and between the juridical order and life" $(2005,12)$. Exception is, more importantly, becoming the rule of state governance, as the following quote clearly demonstrates:

'The state of exception tends increasingly to appear as the dominant paradigm of government in contemporary politics. This transformation of a provisional and exceptional measure into a technique of government threatens radically to alter - in fact, has already palpably altered - the structure and meaning of the traditional distinction between constitutional forms' (Agamben 2005, 13).

In his interpretation of Agamben's theory, Salter argues that "the border is a permanent state of exception, which makes the 'normal' biopolitical control of government inside the territorial frontier of the state possible" by making it possible to "institutionalize a continual state of exception at the frontier that in turn performs the spatio-legal fiction of territorial sovereign and the sovereign subject in each admission/exclusion decision" $(2008,365)$.

As both authors imply, the state of exception is not a suspension of the law; rather, a legitimised space where sovereign power can be exercised by a handful of individuals that are allowed to impart a 'decision without recourse, without appeal, and without debate' (Salter 2008, 368). Typical of sovereign power is, first of all, the determination of a zone of anomie where 'all legal determinations - and above all the very distinction between public and private - are deactivated' (Agamben 2005, 61). These zones of anomie are excluded from the political space of the state but are still, according to Agamben, part of that space; more specifically, its very condition. The freedom to include or to exclude from the law is also a key feature of sovereign power, as 'the decision to admit to the safe haven of the 
domestic or expel into the dangerous world is precisely a decision to include the subject to the law or exclude the subject from the law' (Salter 2008, 369).

In Border Politics: The Limits of Sovereign Power (2009), Vaughan-Williams draws on Agamben and Foucault when observing that the production of a biopolitical body, whose life resides right at the centre of modern politics, is the original activity of sovereign power. The relationship between politics and life is, in other words, the very principle behind this conceptualisation of power. Who retains the power has the right to decide on the lives of citizens and non-citizens. For Agamben, the activity of sovereign power relies on governments' decisions whether certain forms of life are worth living. This is not merely an exclusion of the other, but brings out a cascade of events, mainly the anxiety and uncertainty that our rights, as human beings, are subjected to a bureaucratic governmentality of discretion.

'Borders represent a legal admission by a sovereign into the domain of his/her authority and protection' (Salter 2008, 371). I argue that, by doing so, they act as social institutions that, by virtue of their legitimacy, exercise an arbitrary form of sovereign power within an allocated space. In other words, 'the spatial allocation of authority is the stable institutional core of the border' (Müller 2013, 354).

A final characteristic of sovereign power, which is identified by both Agamben and Vaughan-Williams as typical of modern states of exception, is the determination of a state where zoé can be taken as bios. Drawing upon Foucault's definition of biopower as the 'right of death and power over life', power is here conceptualised 'as the decentred network of bodily, face-to-face confrontations, and ultimately as the productive penetration and subjectivizing subjugation of a bodily opponent' (Foucault in Habermas 1994, 63-64).

Foucault described biopower as existing side by side with the sovereign power: a legislative, prohibitive and censoring form of power (Foucault 1978). Here, we need to stretch Foucault's theory, as Agamben and Salter did, in order to understand how it can be applied to the ideology of the border.

To Salter, the border is a permanent state of exception which renders the limit of sovereign power both visible and invisible (Salter 2008, 377). On the one hand, the visibility of sovereign power is evident in the fact that it retains the right to refuse any request of citizenship and belonging, and exercises that right at each and every border examination.

On the other hand, in Fortress Europe: Inside the war against immigration, Matthew Carr argues that border controls, regardless of their objectives, all share a common 'determination to limit and control the movement of unwanted and potentially dangerous people' (2015, 13). From East Europe to the borders of Ceuta and Melilla, not only 'European governments have reinforced their borders with police, soldiers, border guards, naval patrols, physical barriers and detection technologies' $(2015,3)$, but this extensive border programme has been sustained with no interest for the rights and welfare of those who attempt to cross maritime and terrestrial borders every day.

The sovereign decides whether the border crossers constitute a danger to the sovereign. Quite poignantly, Agamben points out that 'the relation of the exception is the relation of ban. He who has been banned is not, in fact, simply set outside the law and made indifferent to it but rather abandoned by it, that is, exposed and threatened on the threshold in which life 
and law, outside and inside, become indistinguishable' $(1998,28)$. This is precisely the space where the relationship between bodies and violence, as encrypted within the sovereign power, can be exercised in a legal and broadly accepted manner.

Furthermore, leaving aside the differentiation between visibility and invisibility for a moment, we can safely assume that borders are, in fact, performances of sovereign power where 'border agents and state bureaucrats play a critical role in determining where, how, and on whose body a border will be performed' (Butler 2004, 66). Lost in-between a space that is in and outside the political space of a state, the borders represent an area that is excluded from the political space of the state but still an integral part of that space; probably, its very condition of existence. It is a space where the 'normal' order is suspended and anxiety becomes the normal technique of government; in Schmitt's words, a place of nothingness that is neither inside nor outside the state (cited in Vaughan-Williams 2009).

These logics and frameworks of the border, while reflecting different notions of what form of life is eligible for protection, constitute the space where it is possible for some humans not to be treated as equal. As Carr rightly points out while recalling a Human Rights Watch report from 2005, a consistent number of asylum seekers in Ukraine was 'routinely detained in appalling conditions; subjected to violence, robbery, and extortion; denied legal assistance; and in some cases sent back to countries where they face persecution and torture' $(2015,43)$. Needless to say, this situation is not limited to Ukraine. Similar episodes of violence under the name of the sovereign power have happened at the borders of Spain since the 1990s against illegal immigrants; at Greece's land border with Turkey since 2012 in the form of push-backs and mass expulsion; or at the Hungary-Serbia border since 2011, just to name a few examples (source: Amnesty International, 2015).

I agree with Carr on the fact that 'democratic principles of accountability, transparency and the rule of law are not compatible with cultures of impunity in which even the most grievous violations of human rights - including the right to life - are not investigated or punished' $(2015,263)$. Principles of human dignity are constantly undermined and buried under overexaggerated concerns for security and safety. Behind these concerns, what is left is the identification of the refugees as bare lives, which is the focus of the following section.

\section{Borders as processes of identity formation}

As Salter points out, 'sovereignty and subjectivity cannot be examined in isolation' (2008, 372). On the contrary, borders have a crucial impact on processes of identity formation, whichever subject is involved in the discussion: border agents, citizens, or asylum seekers. In this section I focus on the concept of bare life as the 'raw' and undetermined existence of individuals that have no space, no voice and no political agency; people held in waiting at the borders of Europe, as the almost 60 million people who are forcefully displaced around the world due to conflict, violence and persecution are (source: UNHCR).

As I discussed previously, 'the sovereign retains the absolute right to refuse any claim of citizenship and belonging, and exercises that right at each and every border examination' (Salter 2008, 375). That being said, if sovereign power has the ability to decide which lives are worthy of living and which are not, then bare life is the product, and the object, of such ability. For Agamben, the 'production' of bare lives within the political space becomes apparent with the reversal of the democratic state into totalitarian regimes at the beginning 
of the 20th century, when unwanted and unwelcomed individuals have been 'constructed' as disposable bare lives that could be destroyed with impunity. If sovereign power decides who is entitled to become a productive member of any given society, and who has to be excluded from the polis, than it is clear that the consequences of such discretionary decisions affect the individuals on multiple levels, first of all on their senses of identity and belonging.

Bare life is, therefore, life that has been reduced to biology whilst its political existence and citizenship status have been withdrawn. In Agamben's terms, the identification (and distinction) of citizen vs. non-citizens stands at the core of the modern nation-state. That being said, if we think about the implications of being recognised as citizens, namely the opportunity to claim for basic rights, it becomes clear that nude vite (bare lives in Italian) are lives devoid of any value.

This is also ratified by Vaughan-Williams in his analysis, as the following quote demonstrates: 'the sovereign decision bans bare life from the legal and political institutions to which citizens normally have access. This ban renders bare life amenable to the sway of sovereign power and allows for exceptional practices such as torture, rendition, or execution' $(2009,99)$. The indistinction between zoē - our essential 'nature' which we have in common with all creatures - and bios - our political determination as members of a given community - in contemporary political life is what makes it possible to 'create' lives that, when deprived of their political contingency, can be treated as animals.

According to Agamben, refugees can be seen as the ultimate 'biopolitical' subjects: lives that can be determined and controlled in a permanent 'state of exception' outside the normal legal framework, namely the camp. "In camps, he argues, refugees are reduced to 'bare life': humans as animals in nature without political freedom" (Owens 2009, 568). Drawing upon Butler's Precarious Life (2004), border performances create people in waiting, lives that can be put on hold regardless of any consideration for their survival. In this respect:

'The function of modern international organisations is to manage refugee populations in a manner that does not radically undermine the framework on which the nation-state rests. The three principal solutions to refugees repatriation, integration into the society to which they have fled, or resettlement in a third country - all affirm the classical trinity of nation/state/territory with its ideas of citizenship and rights. Eventually refugees must either return 'home' or be naturalised somewhere else. But, more fundamentally, refugee populations are produced and governed as subjects amenable to public and private management techniques - the techniques now closely linked to the rationalities of economic globalisation' (Owens 2009, 571).

This lack of consideration for people's survival emerges very clearly in some of the stories reported by Amnesty International (2015). The following is the story of a 31-year-old Syrian refugee and his experience of a typical push-back from Greece's land border with Turkey in April 2015, which I think is quite relevant to the argument presented here:

'They took us to the river bank and told us to get on our knees. It was dark by this time - about $8.30 \mathrm{pm}$. There were other people there who were being sent back to Turkey. One of the police hit me on my back ... he hit me on my legs and on my head with a wooden stick. They took us closer 
to the river and told us to be quiet and not to move. They took me away from the group and started beating us with their fists and kicking us on the floor. They held me by my hair and pushed me towards the river' (https://www.amnesty.org/en/latest/news/2015/11/refugees-endangeredand-dying-due-to-eu-reliance-on-fences-and-gatekeepers/)

At Bulgarian border controls, things are not very different, as the following quote demonstrates:

'We said we are Yezidis from Iraq, that there are terrorists in our country, that Daesh [Islamic State] persecutes us, and that we came to Bulgaria only for finding peace. The police said ' $\mathrm{Ok}$, ok, I understand'. They told us to get in the car. We thought they'd take us to Sofia, but they brought us near a small river after about 30 minutes of driving. There was a chair there and a tent [...].There was no one else but us and these two policemen. When they took us out the car, they started to beat us with their hands and the truncheon. They hit everywhere. Not too bad, so we were not injured, but it was humiliating. They took all our money and our phone. The phone wasn't even something expensive, just a normal Nokia. But they took it anyway. We had a Turkish sim card in it and they took it out. Using hand gestures and bad English, they told us to cross the river to the other side. It was a small river. We had only one mobile amongst ourselves. We asked to be given back the mobile so that we could ask help. But they didn't even give the mobile back. We were really scared. They pushed us and hit us. It was horrible. They showed the other side, said 'Sofia, Sofia'. They were obviously lying. We found out, it was Greece' (Amnesty 2015, 56).

According to Amnesty International,

'...most of the people who claimed to have experienced push-backs whether at the land border or at sea - said that they either experienced or witnessed violence or degrading treatment. People described being slapped, kicked, beaten and manhandled. Almost all of those interviewed described being searched and most said that their mobile phones, sim cards, money, jewellery, bags of spare clothes, documents or family photographs were confiscated - the belongings were either not returned or thrown into the sea. Some of the interviewees said that they were stripsearched, which they described as humiliating. All those who claimed to be pushed back from Greece to Turkey reported that they were never given an opportunity to explain their situation or challenge their deportation' $(2015,59)$.

From a human rights point of view, this is clearly unacceptable. From a political point of view, this is perfectly justifiable. These forms of power and control are perfectly acceptable. In fact, as Butler rightly points out, these practices are fully discretionary, arbitrary, and perpetuated by officials (border guards) that have the power to interpret the law as they prefer, and to decide the 'condition and form of their invocation' $(2004,62)$. This is a delegitimization of the human, a life that is reduced to a biological minimum, suspended in an extra political space for an indefinite term with nowhere to go and no place to come back to. 
The discretion used by the sovereign power is evident in the following extract from Fear and Fences:

'After an incident on 6 February 2014 involving the summary return of 23 individuals who had swum to the shores of Ceuta, the Spanish Minister of the Interior claimed that it was legal to deport the 23 because they had not yet crossed the Spanish border, which he stated was the human border made by the Civil Guard officers. Such statements demonstrate that the Spanish authorities are willing to redefine where Spanish territory begins on a case-by-case basis in an attempt to avoid their international obligations' (Amnesty International 2015, 31).

To Agamben refugee camps and, I argue, border controls, are the places in which biological and political life, private and public, cannot be distinguished from each other. Naked life is revealed as the underlying concept of sovereignty. 'The same bare life that [...] in the classical world was (at least apparently) clearly distinguished as $z o \bar{e}$ from political life (bios) now fully enters into the structure of the state and even becomes the earthly foundation of the state's legitimacy and sovereignty' (Agamben 1998, 127).

And yet, this is considered normal by the sovereign power, where the exception becomes the norm. Only the 'sovereign' can decide when and where the law can be suspended, whether a state of emergency should be declared, or whether human rights legislation can be 'circumnavigated'. They reveal the fundamental structure of the rule of law and the real character of juridical and political order (see also Marino 2015).

\section{Borders as performances of denial}

This final section has been inspired by Gavan Titley's paper 'The debatability of racism. Networked participative media and postracialism ${ }^{3}$, , and in particular by the author's following statement that refers to the current border crisis: 'a racial Europe is being resecured through an intensive mobilization and fusion of both nationalism and liberalism, of both extremist ideology and the re-composition of governmentality'. It seems to me that resecuritization is also a process of re-assurance, in at least two ways: firstly, and from a citizen point of view, we need to be reassured that someone else is doing the 'dirty work' for us, while taking care of our needs and desires to be safe. Secondly, and from a purely political point of view, the borders seem to reaffirm a sense of authority, trust, and accountability that European governments seem to have lost before and in the immediate aftermath of the Eurozone crisis. It is for our security, they say. It is necessary, it is worth our money, it is an indispensable measure that will keep our countries safe.

Borders are, I believe, at the very core of this political and communicative process of trust in the sovereign power, which rapidly turns into the obsolescence of what is actually happening outside our legitimate spaces of citizenship. As performances, they are not natural, but exist as practices and processes of identification ( $u s v s$. them) and of exclusion. I also argue that borders are not merely performances of states of exception (Agamben 2005),

\footnotetext{
3 Keynote lecture given at the ECREA's Diaspora, Migration and the Media Section Conference 'The porous walls of Fortress Europe' (Erasmus University, Rotterdam 19 November 2015). The paper is available online from: http://raster.fi/2016/02/17/the-debatability-of-racism-networked-participative-media-and-postracialism/
} 
but also performances of denial. I here intend the term 'denial' as a process of degradation of this 'humanity on the move' that demands a global response from the Union, but also as denial of lives that simply do not matter. In this process of human and political obsolescence, disposable lives are produced and replicated in the inefficiency of European policies and bordering practices.

As Victoria Esses rightly points out, 'in the current global climate, immigration and refugee policies are a hot topic of debate and there is little direct information available to the public to answer their questions. This creates an opportunity for the media and political elites to grab the public's attention, alerting them to supposed physical, economic, and cultural threats from immigrants and refugees as they transform relatively mundane episodes into newsworthy events that can be sold to the public and serve as support for relatively extreme political platforms' (http://phys.org/news/2013-09-media-role-dehumanizing-immigrantsrefugees.html\#jCp).

This considered, the resultant dehumanization of immigrants and refugees, their determination as bare lives that do not really matter as they are economically and politically 'unworthy', serve to justify the status quo, strengthening the boundaries between us and them, and defending us against supposedly incoming threats.

\section{Conclusions}

This article has emphasised the centrality of borders as a central asset of European homeland security policy. While defining borders as institutions, processes and performances, I have argued that these spaces embody a permanent state of exception where contingent and politically charged meanings of identity and subjectivity dominate the exercise of sovereign power. In these hybrid spaces of indeterminacy, refugees are objects of violence, as bare lives that are suspended in-between two non-spaces: a space - the border - where the normal order is suspended in favour of arbitrary acts of power; and the space they leave behind in order to seek a better life. On the one hand, we can imagine ways to respond to the crisis, measures that European governments can adopt; for example, by expanding safe and legal channels, by ensuring access to asylum and humane treatment at its borders, by increasing refugee resettlement and facilitating family reunification, or by providing humanitarian visas and ensuring fair and equal asylum procedures in the respect of human rights ${ }^{4}$. On the other hand, and from a theoretical point of view, we should perhaps recognise that what is at stake here, when border security becomes a normal technique of government, is the crisis of the whole of humanity, and its inability to guarantee a fair and equal protection to all.

Borders are the emblem of the absence of a shared responsibility among the countries in the Union, a 'catastrophic failure' of principles of justice and collective solidarity, which 'raises crucial questions about human rights and global inequality, about security, migration and the obligations of governments to refugees and non-citizens' (Carr 2015, 7).

I would like to conclude with a note from Gavan Titley's 'sedimentation of denial'. Racism and migration are, too often, good companions. The denial of such a relationship often creates the problem rather than explaining it. Quite bluntly, we show compassion towards

\footnotetext{
${ }^{4}$ See Human Rights Watch's report Europe's Refugee Crisis: An Agenda for Action (November 2015). Available at: https://www.hrw.org/report/2015/11/16/europes-refugee-crisis/agenda-action
} 
the fate of refugees living and trembling at the border of our comfortable homes; we watch the news, we read the newspapers, but then a veil of indifference rapidly covers any sort of concrete discussion about them. Governments, on the other hand, perceive refugees as unwanted and unwelcome guests trying to impose their presence over already saturated gates. Most of the time, states try to 'wash-out' their responsibility by leaving other countries to deal with the 'problem'. A global response to this humanitarian crisis has, unfortunately, still a long way to go.

\section{References}

Agamben, G. (1998) Homo Sacer: Sovereign Power and Bare Life, Stanford, CA: Stanford University Press

Agamben, G. (2000) Means without ends: notes on politics, Minneapolis: University of Minnesota Press

Agamben, G. (2005) State of exception, Chicago: University of Chicago Press

Amnesty International (2015) 'Fear and Fences: Europe's approach to keeping refugees at bay' [online], 17 November. Available at https://www.amnesty.org/en/latest/news/2015/11/refugees-endangered-and-dying-due-toeu-reliance-on-fences-and-gatekeepers/. Accessed 6 March 2016.

Balibar, É. (2009) 'Europe as Borderland', Environment and Planning D: Society and Space, 27 (2), 190-215

Bunyan, T. (2010) 'Just Over the Horizon-the Surveillance Society and the State in the EU', Race \& Class 51(3), 1-12

Butler, J. (2004) Precarious Life, New York: Verso.

Carr, M. (2015) Fortress Europe. Inside the war against immigration, London: Hurst \& Co Esses, V., Medianu, S., and Lawson, A.S. (2013) 'Uncertainty, Threat, and the Role of the Media in Promoting the Dehumanization of Immigrants and Refugees', Journal of Social Issues 69 (3), 518-536. Abstract online available at http://phys.org/news/2013-09-mediarole-dehumanizing-immigrants-refugees.html\#jCp. Accessed 6 March 2016.

Foucault, M. (1978) The History of Sexuality, Volume 1: The Will to Knowledge, London: Penguin.

De Genova, N. (2010) 'Migration and Race in Europe: The Trans-Atlantic Metastases of a Post-Colonial Cancer', European Journal of Social Theory 13(3), 405-419

Habermas, J. (1994) 'The Critique of Reason as an Unmasking of the Human Sciences: Michel Foucault', in K Michael (ed.), Critique and Power: Recasting the Foucault I Habermas Debate, Cambridge, Massachusetts/London: MIT Press, pp. 47 - 78 
Human Rights Watch (2015) 'Europe's Refugee Crisis. An Agenda for Action' [online], 16 November. Available at https://www.hrw.org/report/2015/11/16/europes-refugeecrisis/agenda-action. Accessed 6 March 2016.

Malkki, L.H. (1995) 'Refugees and Exile: From "Refugee Studies" to the National Order of Things', Annual Review of Anthropology 24, 495-523

Marino, S. (2015) 'Surviving mechanisms of power in immigration strategies: embracing Otherness and pluralisms', Journal of International Political Theory 11 (2), 167-183

Müller, A. (2013) 'Issues of Europe-Making. Territorial borders as Institutions. Functional change and the spatial division of authority', European Societies 15(3), 353-372

Owens, P. (2009) 'Reclaiming 'Bare Life'?: Against Agamben on Refugees', International Relations 23 (4), 567-582

Salter, M.B. (2008) 'When the exception becomes the rule: borders, sovereignty, and citizenship', Citizenship Studies, 12 (4), 365-380

Titley, G. (2015) 'The debatability of racism. Networked participative media and postracialism' [online]. Available at http://raster.fi/2016/02/17/the-debatability-ofracism-networked-participative-media-and-postracialism/. Accessed 6 March 2016.

Vaughan-Williams, N. (2009) Border Politics. The Limits of Sovereign Power, Edinburgh: Edinburgh University Press

Walters, W. (2002) 'Mapping Schengenland: Denaturalizing the Border', Environment and Planning D: Society and Space 20 (5), 561-580

Sara Marino is a Teaching Fellow in Digital Culture at the Department of Digital Humanities at King's College London. She holds a $\mathrm{PhD}$ in Communication Science from the University of Urbino (Italy), where she worked on digital media and diaspora. Her doctoral dissertation, "Online and offline diasporic communities. Italians in London", examined the use and impact of Internet technology on immigrants' identity, sense of community and ideas of belonging.

She previously worked as a Visiting Lecturer at the University of Westminster, and as Associate Lecturer at Central Saint Martins - University of the Arts.

Her main research focuses on the social understanding and analysis of digital diasporas from a political economy perspective that seeks to explore how the socio-economic European scenario has affected intra-European migration. More recently, she became interested in the study of borders and transit zones, especially in relation to the refugee crisis and to the idea of Fortress Europe.

Email: $\underline{\text { sara.marino@kcl.ac.uk }}$ 